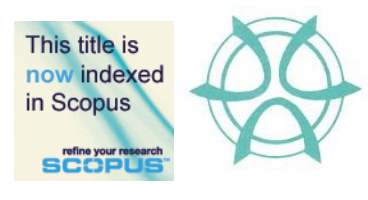

PLANNING MALAYSIA:

Journal of the Malaysian Institute of Planners

VOLUME 15 ISSUE 3 (2017), Page 63 - 76

\title{
INTEGRATED PLANNING MODEL OF CREATIVE INDUSTRY- BASED KAMPUNG TOURISM IN JAYENGAN SURAKARTA, INDONESIA
}

\author{
Winny Astuti ${ }^{1}$, Ariva Sugandi Permana ${ }^{2}$, Qomarun $^{3}$, Alpha Febela ${ }^{4}, \&$ \\ Rufia Andisetyana ${ }^{5}$ \\ ${ }^{1,5}$ Program Study of Urban and Regional Planning \\ UNIVERSITAS SEBELAS MARET SURAKARTA, INDONESIA \\ ${ }^{2}$ Department of Urban and Regional Planning \\ UNIVERSITI TEKNOLOGI MALAYSIA \\ ${ }^{3,4}$ Department of Architecture \\ UNIVERSITAS MUHAMMADIYAH SURAKARTA, INDONESIA
}

\begin{abstract}
Creative Industry-based tourism has been popular as several cities in Indonesia have also been declared as "Creative City". In sustainability viewpoint, the integration of creative industry activities with other planning elements and efforts towards social and economic development is necessary. The inter-organizational collaboration is essential by integrating various disciplines in managing the complexity and the dynamics in tourism development. This research aims at developing an Integrated Planning Model of Creative Industry-based Tourism in Jayengan Surakarta. The study adopted a mixed-methods approach using detailed observations and interviews, as well as Focus Group Discussion (FGD) with the primary actors to understand the process. The study suggests that creative industry-based kampung tourism in Jayengan Surakarta, must be developed with integrated manner through interrelationships among tourism components, developing problem-solving model, promoting a conceptual system to guide the process and strengthening the inter-organizational collaboration. It is also understood that this concept might promote rural development since the potential sources of local industries and tourism are abundantly available in the rural areas.
\end{abstract}

Keywords: Creative industry, Integrated Planning Model, tourism, community, kampong

Date Received: $11^{\text {th }}$ February 2017

Date of Acceptance: $15^{\text {th }}$ September 2017 
Winny Astuti, Ariva Sugandi Permana, Qomarun, Alpha Febela, \& Rufia Andisetyana

Integrated Planning Model of Creative Industry-Based Kampung Tourism in Jayengan Surakarta, Indonesia

\section{INTRODUCTION}

Along with the issue of mega cities in some Southeast Asian countries (McGee, 2009; Scott, 2001), the urban poverty rate is also increasing in parallel with the increase in rural-to-urban migration. A high poverty rate in Indonesia, which was in 2014, have reached 27.73 million people or $10.96 \%$ in average (BPS Nasional, 2016) has forced Indonesia to emphasize and prioritize economic development in the national planning system. In Surakarta itself, which is the study area of this paper, the poverty rate was even higher than national average, which was at $14.1 \%$ in 2009 (BPS Surakarta, 2016).

One of the development sectors, which has multiplier effects on enhancing economic development and people welfare, is tourism sector. As found in Kampung Jayengan Surakarta, the inhabitants are Banjarnese, whose ancestors came from the Banjar Area in Southern Kalimantan as early as 1746. Their ancestors were traders in jewellery, a trade which was inherited for generations up until today. They firstly built the Darussalam Mosque as a centre of Moslem religion, cultural and education activities in the area. Nowadays, the jewels craft of Kampung Jayengan has a great potential along with original Banjarnese traditional culinary, called Banjar Porridge (Bubur Banjar) event, traditional dance of Hadrah etc. However, these days, the traditional characters of Jayengan have been threatened by the urban development, as the area is located in the centre of a business district. Exploring the traditional values of the Jayengan to boost the community-based urban economy is one of the ways to eliminate urban poverty while exploring the high potential creativity of the citizens. Within the context of rural-urban connectivity, creative industry may also generate the symbiotic mutualism as the industry provides opportunities for suppliers in the rural areas and markets in the urban areas, and in the end, may create economic opportunities for both urban and rural people (Cunningham, 2002; Garnham, 2005; Ma \& Zhu, 2016).

The creative industry-based tourism potentials are richly available in both urban and rural areas, particularly in rural areas (Evans, 2009; Dorry, Rosol \& Thissen, 2016; Lu \& Chang, 2016). In the case of the study area, the rural area reserves the perspectives of the industry along with cultural and natural based tourism potentials, for example, in the buffer areas of Surakarta City. Three ethnic groups of Banjarnese, Javanese and Chinese (locally known as Jarwono) promote creative industry in Jayengan Kampung Permata (JKP).

This study aims at developing Integrated Planning Model of Creative Industry-based Tourism Kampung in Jayengan, Surakarta. The study attempts to respond to questions on how the model able to integrate all components of creative industry-based tourism in the development process of Jayengan as creative industry-based tourism Kampung. 

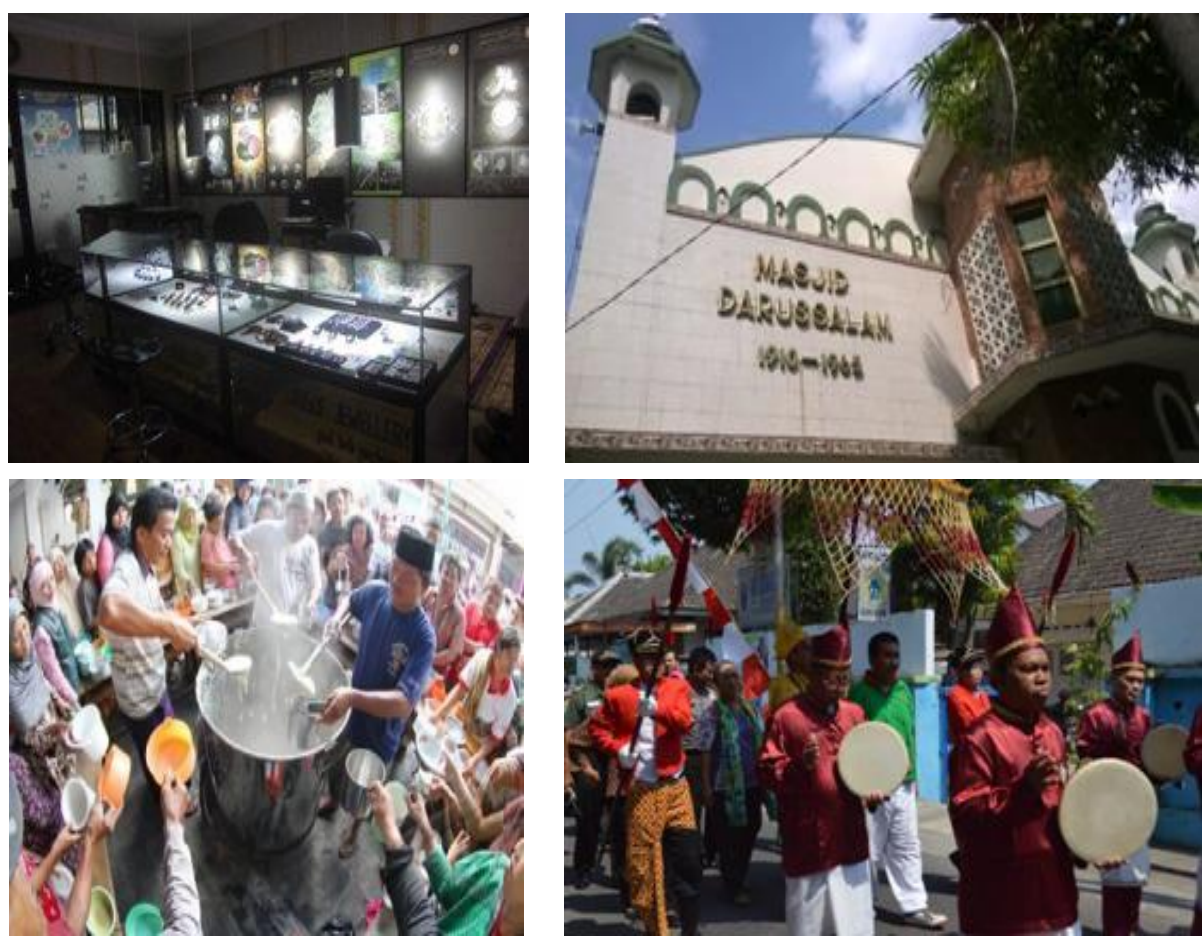

Figure 1 The Main Tourism attraction of Jewel Craft and supporting tourist Attractions Traditions (Photos Credit: Winny Astuti)

\section{THEORETICAL BACKGROUND ON THE MODELS}

\section{Industrial Cluster, Creative Industry and Creative Industry-Based Kampung Tourism}

Porter (1990) refers the industrial cluster to an agglomeration and spatial concentration of industrial activities, which has one specialization of industry. Luo \& Tung (2007) assert that intense relationship among concentrated business units in the form of partnerships generates an industry with broader market opportunities as well as export market. If it is translated into urban planning theory, industries concentrated in one location is more desirable than scattered, as home-based economy must be able to generate the income while development control is loosely carried out (Lambert \& Boons, 2002; Gronau, 1980). Porter (2000) argues that partnerships are formulated when each of business units in industrial cluster develops networking with other business units internally, as well as other different clusters with different function and roles. Variety of business units with different characters and roles contribute to sustainability of industrial chain as component of industrial cluster. Based on Porter (1998) and 
Winny Astuti, Ariva Sugandi Permana, Qomarun, Alpha Febela, \& Rufia Andisetyana

Integrated Planning Model of Creative Industry-Based Kampung Tourism in Jayengan Surakarta, Indonesia

Setiyani (2014), there are three main components of industrial cluster: core industries, supporting industries, and related industries.

Sihombing et al. (2016) assert that cluster approach in tourism-based kampung development should be based on the strengthening of the quality of relationships among associated business chains for improving the effectiveness and competency of the kampung as tourism destination. By this assertion, the existence of tourism-based kampung with creative industry as prime mover should have an interconnection with the city planning system. Information Technology (IT) will help strengthening and broadening the network of this kampung tourism. Meanwhile, the creative tourism refers to tourism destinations that offer tourists the opportunity to develop their own experience through active participation in learning experience (Landry, 2012).

\section{Model for Tourism Planning and Development}

According to Getz (1986) and Jafari (1987), there are several models in tourism planning, which include theoretical and process models. While the theoretical model conceptually depicts how the planning itself relates to reality, the process model is basically a subjective/prescriptive type which is based on dogma or idiosyncratic reaction as well as based on problem-solving that formulate goals, generate alternatives, evaluate the alternatives and options, and implementation. Another model is integrative model, which is a complex approach based on systems theory. At this point, these varieties of planning models are applicable to kampung Jayengan. In line with this, Gunn (2014) and Bello, Car and Lovelock (2016) argue that sustainable tourism planning should integrate all planning elements and efforts for social and economic development as an interactive system.

In the process models, the problem-solving approach seems suitable to the Jayengan. This problem solving model has 3 subsystems namely area development, project development and management and marketing. Baud-Bovy (1982) developed a model based on comprehensive approach for tourism development master plan. Another similar model is integrated planning model that allows planners to understand the systems and interrelationships among tourism components.

\section{Integrated Planning Model}

Sautter \& Leisen (1999) stated that collaboration of stakeholders in tourism development is a primary key for sustainable development efforts in tourism development, and use transactional strategies as development instruments. However, development of mechanism and process for integration and collaboration of all various interests and elements in tourism system is still a strong challenge. It needs strong cooperation and collaboration from all stakeholders of tourism planning (Jamal \& Getz, 1995; Sautter \& Leisen, 1999; 
PLANNING MALAYSIA

Journal of the Malaysia Institute of Planners (2017)

Bramwell \& Lane, 2000; Aas, Ladkin, \& Fletcher, 2005). Collaboration in this case is more than a cooperation, which is usually working together to some end. A collaboration is beyond a cooperation, which shares the goals to be accomplished (Jamal \& Getz, 1995; Reed, 1997). Therefore, collaboration for community-based tourism planning should be beyond a process of joint decisionmaking among autonomous key stakeholders of an inter-organizational community tourism domain to resolve planning problems of the domain and/or to manage related issues (Graci, 2013).

\section{RESEARCH METHODS}

This research applies mixed methods approach. According to Johnson, Onwuegbuzie \& Turner (2007) a mixed method is the type of research in which a researcher or team of researchers combined elements of qualitative and quantitative research approach for the broad purposes of wide and deep understanding and corroboration.

An ethnographic research was carried out for more than three years as most of the researchers live in the same city and shares the same experience with Kampung Jayengan community. Techniques adopted include observation, interview with key persons and Focused Group Discussion (FGD). The key persons in the FGD include informal community leaders e.g. religious groups and noblemen; formal community leaders e.g. Heads of Community (Rukun Tetangga, RT; and Rukun Warga, RW), handicraft persons, tourism actors, local authorities, academics, and NGOs. They were expected to represent their interests towards better performance of creative industries in the study area. The ethnographic survey was conducted to uncover the activities of creative industry actors. This included a sum of 415 creative industry actors covering three different ethnic groups Banjarnese (151), Javanese (185), and Chinese (79). The surveyors gathered the information candidly without being noticed as researchers by the creative industry actors. This was to capture the plain and natural attitude of the actors.

\section{RESULTS OF THE STUDY}

\section{Integrated Components of Planning in Creative Industry-based Kampung of Jayengan}

\section{Integrated Attractions}

The unique characteristics of place, locality and authentic tourism attraction are the main motivation of people visiting tourism destination areas. Kampung Jayengan demonstrates a new opportunity on specific tourism exhibition in Surakarta, as production process of Jewel Craft becomes a unique experience chased by many domestic and international visitors. This primary tourism product 
Winny Astuti, Ariva Sugandi Permana, Qomarun, Alpha Febela, \& Rufia Andisetyana

Integrated Planning Model of Creative Industry-Based Kampung Tourism in Jayengan Surakarta, Indonesia

of Kampung Jayengan is supported by other local interests, such as localtraditional culinary; traditional dance and cultural events of Bubur Banjar (Banjar Porridge) held during the month of Ramadhan; Hadrah dance and other religious events centred in Darussalam Mosque. Thus, the month of Ramadhan is regarded as a right time to organize traditional events in the locality. By this event, we identified some tourist attractions as exhibited in Figure 2.

\section{Integration of National and Local Policies on JKP}

Tourism planning is convoluted due to the interdependency between the tourism development, socio-economic development and interdependency in the internal aspects of tourism such as tourism industry and various segment of the market (Baud-Bovy, 1982). Integration into the national policy is obvious as the planning for tourism destination development relies on the public financing for increasing regional economic development while enhancing the image of the country abroad.

Development of creative industry-based tourism in Jayengan Surakarta has a strong connection with the national policy on BEKRAF (the Agency of Creative Economy), which has been clearly spelt out in the Blue Print of Creative Economy Development of 2015-2025 (BAPPEDA Surakarta, 2015). In connection with the National Policy on Urban and Rural Development, the BAPPENAS (National Planning Development Board) supports the development of creative industry-based tourism kampung implemented through countrywide "One Village One Product". At the city level, the development of creative industry-based tourism in Jayengan Surakarta was supported by City Authority through the Blue Print of Surakarta Creative Industry Development, where Jayengan Kampung Permata (JKP) was declared as one out of 31 industrial clusters in Surakarta. The Surakarta Tourism Board has also integrated the JKP into Destination and Investment Tourism Plan 2016-2026. Program of "City's Kampung Tourism" has been formulated to strengthen the development of JKP. The revitalization of Gatot Subroto Corridor to increase the accessibility to the area has reinforced the exposure of the JKP at local and national level.

At the locality i.e. Kelurahan level, the JKP is the prime program of the annual local plan of Kelurahan Jayengan, in which the Kartopuran square served as the centre of culinary, culture and sports along with JARWONO program, which integrates Javanese, Chinese and Banjarnese ethnics. Integration of the Development of JKP in the development plan indicates that JKP has a high priority development policy. Figure 3 exhibits the overall policy and interconnection among different level of policy directives.

Collaboration with relevant Institutions

Gray (1999) argued that collaboration for community-based tourism planning needs joint decision making between authorities, key stakeholders and an inter- 
organizational community-based tourism domains to resolve the planning problems of the domain and/or to manage issues related to the planning and development of the domain. As Gunn (2014) identified, most problems in tourism industry are due to lack of coordination and cohesion within incoherently tourism industry. Thus, all other planning aspects should integrate with tourism planning. In this case, the JKP should become an effective organizational structure, which caters the collaboration among institutions involve in tourism industry. Firstly, the universities can be involved. Secondly, the government authorities at central and local levels as the most important stakeholders, in which their roles could be played through the setup of social and economic programs implemented by various government agencies. Thirdly, other relevant Community Based Organizations (CBOs) and Non-governmental Organizations (NGOs) such as Batik Community and Solo Creative City Networks could also play the roles of prime stakeholders. Finally, mass media, in which its role is to expand the publicities and to use the information technology for promotion. A proposed collaborative arrangement among stakeholders is shown in Figure 4. Several processes of FGD among related institutions for the development of JKP in the forum have been carried out to share their views towards successful JKP.

\section{National Level Policy on Development of Creative industrial based tourism}

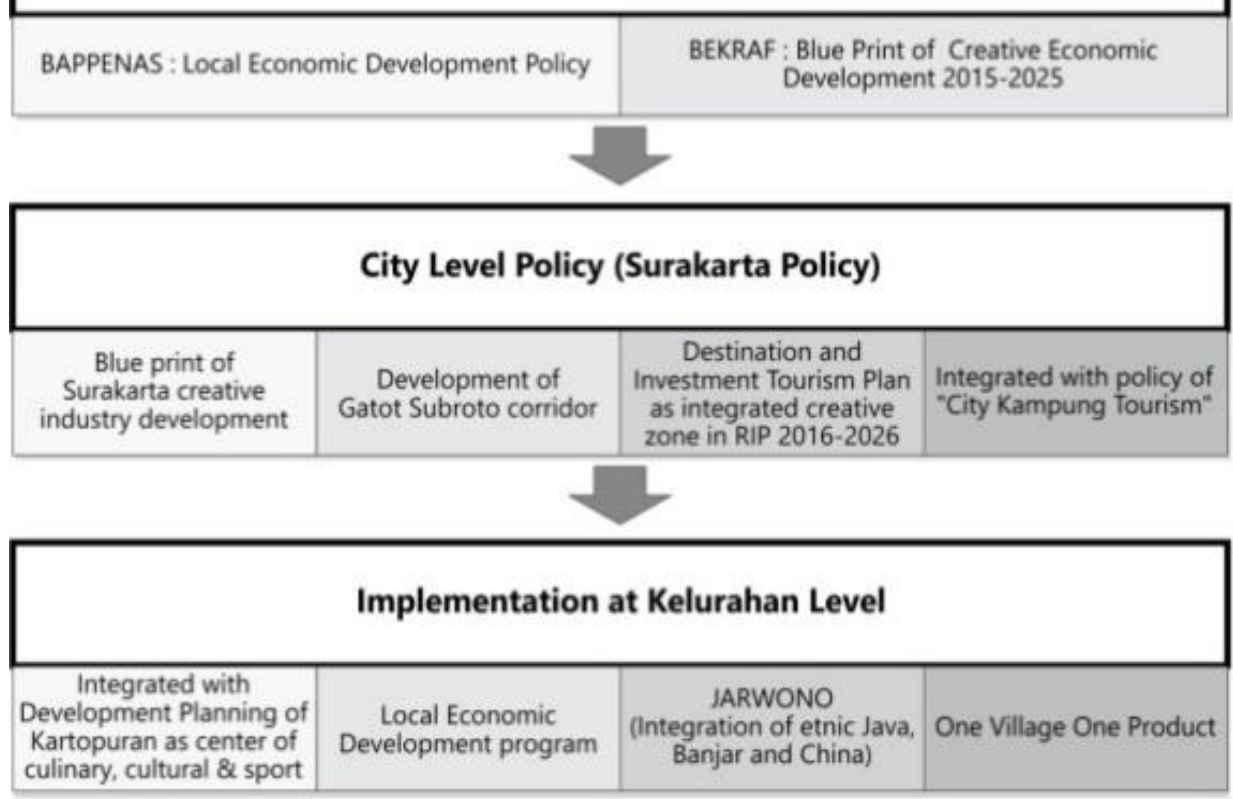

Figure 3 Integration of JKP in National and Local Policy Source: Analysis Astuti, et al 2017 
Winny Astuti, Ariva Sugandi Permana, Qomarun, Alpha Febela, \& Rufia Andisetyana

Integrated Planning Model of Creative Industry-Based Kampung Tourism in Jayengan Surakarta, Indonesia

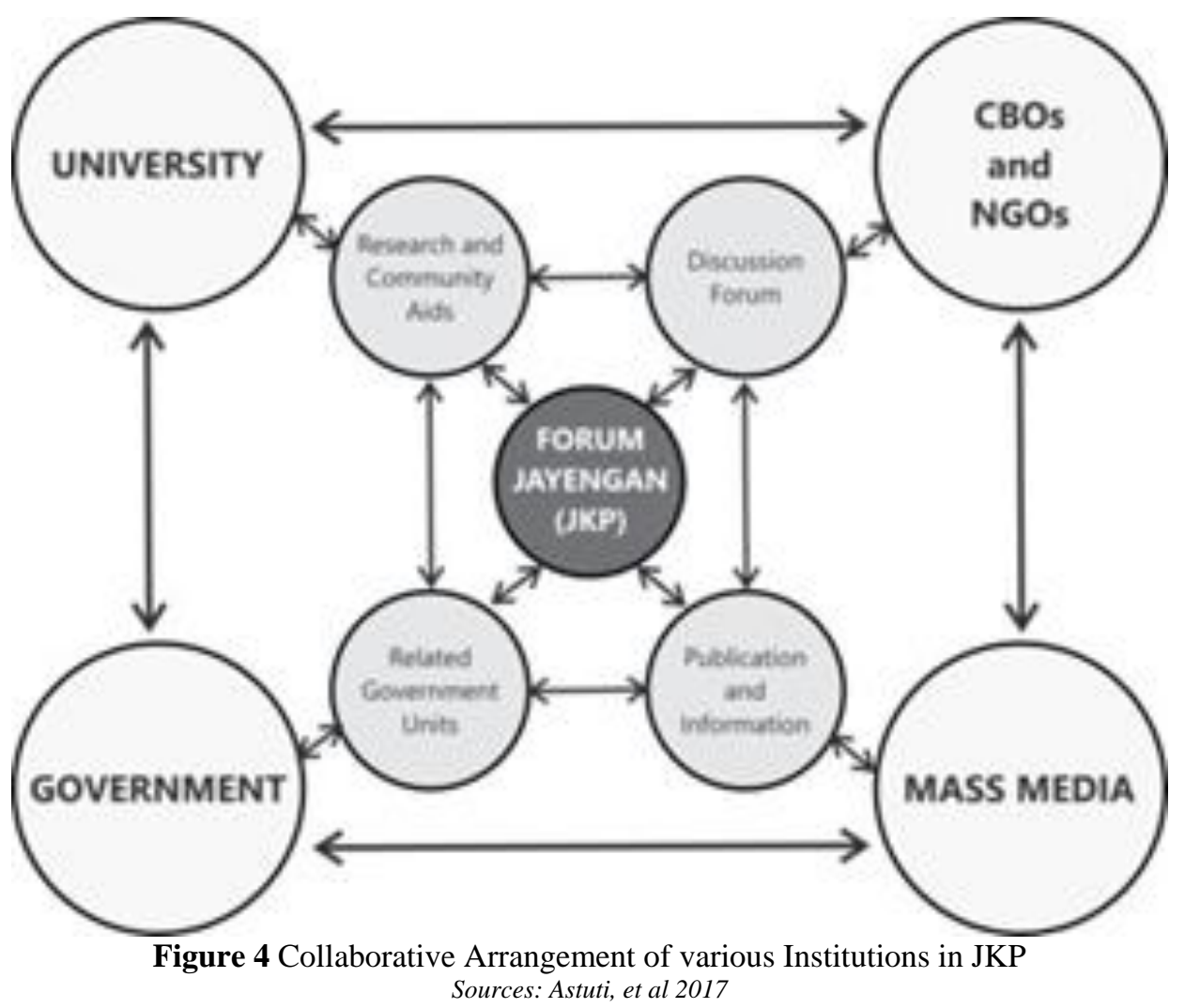

Integration with Associated Economy Sectors

Development of tourism destination area usually leads to enhancing interconnected sectors such as transportation, housing quality improvement, urban economic development, industry, telecommunication and information, urban facilities etc. In the JKP, even though the prime tourist attraction is only jewel industry, but due to strong integration with supporting industries, such as diamond, gold and silver industries, the synergistic actions have happened and flourished. The authorities had also involved the other relevant industries, for example, by integrating Banjar culinary, annual events of Hadrah folklore, Bubur Banjar and other marketable products along with sufficient supporting facilities.

The revitalization of Gatot Subroto Corridor, in which the events took place, the development of associated services, such as hotels, travel agents, museums, and information centres have flourished. This confirms that the development of tourism destination in the study area has multiplier effects in enhancing sociocultural and economic aspects of the city, which definitely brings more positive impacts to the citizens. 
PLANNING MALAYSIA

Journal of the Malaysia Institute of Planners (2017)

\section{Proposed Integrated Planning Model of Creative Industry-based Kampung Tourism in Jayengan Surakarta (IP-CIKT Model)}

The developed model is intended to achieve better planning, coordination, collaboration and development of the JKP itself, as the development of Creative Industry-based Kampung Tourism has multi-sectors' integration, involving several parties such as public sector, private sector, NGOs, community, academics and other relevant entities. This model called IP-CIKT, which integrates the master planning, community-based planning and collaborative planning processes among institutions.

The first step is the development of a Master Plan, which is basically a community development plan, where the process model is based on the problem solving models. It should begin from community understanding of tourism system and theory, problem identification and solution, and goal formulation. The Forum Jayengan Kampung Permata could become representation of the community. Second step is the creation of continuous interaction with community for verification and validation of Kampung characteristics during Community Forum. The process needs simultaneous integration that covers several elements, which are (1) integration of the government policies at national and local levels including Kelurahan/Kampung (2) integration of economic sectors and activities that affect and are affected by the development of JKP (3) integration of the program with both main and supporting industries, and (4) integration of associated socio-economic potentials to support the creative industry-based Kampung Tourism. The third step is the collaboration and integration with government institutions plan as well as private sector and NGO, where the community-based development plan has been formulated in the first place. This process is proposed to generate an appropriate integration of all efforts as well as the commitment of several parties in the development and strengthening interorganizational collaboration towards the successful implementation of creative industry-based Kampung Tourism of Jayengan (see Figure 5). By considering the present status of JKP and all stakeholders involved, the model would reflect better performance of JKP. However, the model needs preconditions, such as city leadership, the courage of the community and collaborative spirit among stakeholders. 
Winny Astuti, Ariva Sugandi Permana, Qomarun, Alpha Febela, \& Rufia Andisetyana

Integrated Planning Model of Creative Industry-Based Kampung Tourism in Jayengan Surakarta, Indonesia

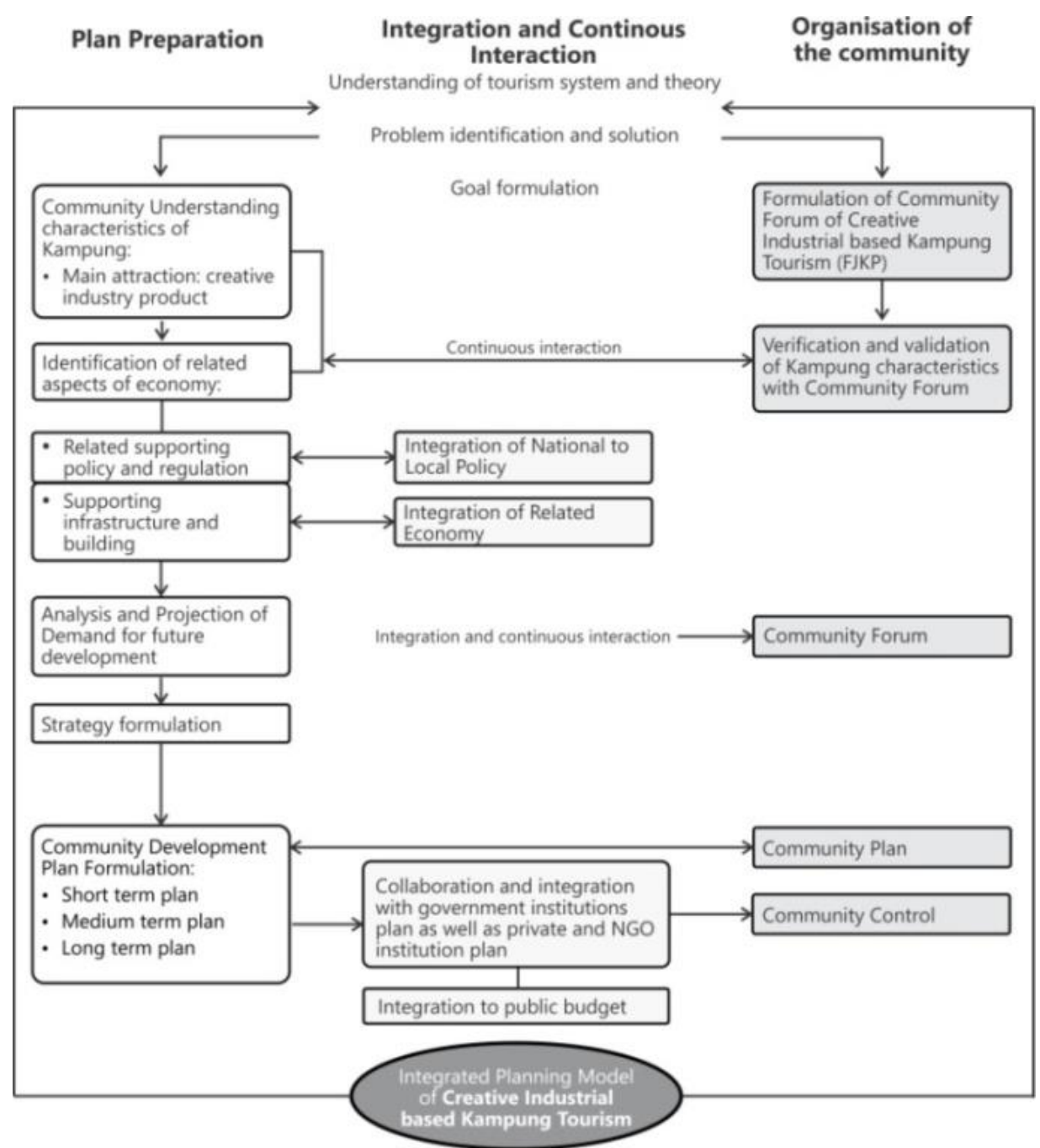

Figure 5 Integrated Planning Model of Creative Industrial -based Kampung Tourism in Jayengan Surakarta (IP-CIKT Model)

Sources : Astuti et al, 2017

\section{The Practicality and Performance}

The prime-mover of the model is the creative industry actors themselves, which consist of three ethnic groups of Banjarnese, Javanese and Chinese. They were formally organized since 2014 towards the vision of JKP with the help of local authorities. A Forum of Economic Development and Employment Promotion (FEDEP) has also played an essential roles to coordinate the process. Presently, the creative industry-based Kampung Jayengan main commodity is mostly jewellery related crafts. The local authority aims for Kampung Jayengan as the 
PLANNING MALAYSIA

Journal of the Malaysia Institute of Planners (2017)

second largest jewellery industry in Indonesia after Martapura in South Kalimantan. It is not impossible since the main actors in Jayengan are also blended Banjarnese who have inherited directly from Martapura. If the situation is brought in the Malaysia context, the situation resembles the Jonker Walk in Melaka where creative industry products are showcased and attracts many domestic and international tourists. However, unlike Jonker Walk Melaka, Kampung Jayengan Surakarta is not an urban heritage and it must grow with its own strengths and advantages. Strengthening and continuous development of the model are therefore necessary to support the vision of JKP. Authorities i.e. City Tourism Department, Cooperative Department, City Planning Department, FEDEP, CBO, NGO and academics must have a good coordination and always provide innovative ways to improve the performance of the model. The actors should be reminded that integration and synergy is the most important and crucial capital towards JKP vision.

The study has also identified that the most significant challenge in the implementation of the model (IP-CIKT Model) is the complexity of the Community-based Organization (CBO) where the community members have different perspectives and orientation to the development of the area. The presence of JKP Forum could be a great platform in the development of JKP, as the Forum becomes an agreed and shared instrument for integration of the community's perspective with other key resources such as government institutions, private institutions, and other similar community forums.

The grand design of JKP development has been prepared through the Forum of JKP, which was initiated by this research. The design should continuously be able to guide and direct the future development of JKP, given that all stakeholders respect the agreement during the JKP Forum. Continuous interaction between JKP Forum and all stakeholders of the JKP development becomes a key success in sustaining the program in Jayengan. Continuous enhancement of local community welfare would contribute to the development of Surakarta as creative city and economic development in the region.

\section{CONCLUSION}

With respect to urban-rural planning context, the potentials of creative industry i.e. actors, creativities and materials are usually plentiful in the rural areas. The only problem is that these potentials have never been exposed as rural economic opportunities and remained hidden without intervention of external forces. If the potentials are channelled to the city and combined with the similar prospective in the city and mainstreamed as part of the city planning as well as urban-rural connectivity, a tremendous economic prospect would be created. By this, urbanrural connectivity could be generated and thus minimise rural-urban divides. 
Winny Astuti, Ariva Sugandi Permana, Qomarun, Alpha Febela, \& Rufia Andisetyana

Integrated Planning Model of Creative Industry-Based Kampung Tourism in Jayengan Surakarta, Indonesia

\section{ACKNOWLEDGEMENTS}

The authors acknowledge the support of Ministry of Research, Technology and Higher Education of the Republic of Indonesia, and the Board of Research and Community Services of UNS and other parties, which could not be mentioned individually.

\section{REFERENCES}

Aas, C., Ladkin, A., \& Fletcher, J. (2005). Stakeholder collaboration and heritage management. Annals of Tourism Research, 32(1), 28-48.

BAPPEDA Surakarta (2015). Blue print pengembangan industri kreatif Surakarta 2015-2025. Board of Planning and Development Surakarta.

Baud-Bovy, M. (1982). New concepts in planning for tourism and recreation. Science Direct, 3(4), 308-313.

Bello, F. G., Carr, N., \& Lovelock, B. (2016). Community participation framework for protected area-based tourism planning. Tourism Planning and Development, 13(4), 469-485.

BPS Nasional. (2016). The percentage of Poor according to Province in Indonesia 2013-2016. Retrieved from https://www.bps.go.id/linkTableDinamis/view/id/1219

BPS Surakarta. (2016). The Poor, the Poverty and Percentage of Poverty in Surakarta 2002-2014. Retrieved from https://surakartakota.bps.go.id/linkTabelStatis/view/id/74

Bramwell, B., \& Lane, B. (2000). Tourism collaboration and partnerships: Politics, practice and sustainability. Channel View Publications.

Cunningham, S. (2002). From cultural to creative industries: Theory, industry, and policy implication. Media International Australia Incorporating Culture and Policy, 102(1), 54-65.

Dorry, S., Rosol, M., \& Thissen, F. (2016). The significance of creative industry policy narratives for Zurich's transformation toward a post-industrial city. Cities, 58(October), 137-142.

Evans, G. (2009). Creative cities, creative spaces and urban policy. Urban Studies, 46(5-6), 1003-1040.

Garnham, N. (2005). From cultural to creative industries: An analysis of the implications of the "creative industries" approach to arts and media policy making in the United Kingdom. International Journal of Cultural Policy, 11(1), 15-29.

Getz, D. (1986). Models in tourism planning. Tourism Management, 7(1), 21-32. https://doi.org/10.1016/0261-5177(86)90054-3

Graci, S. (2013). Collaboration and partnership development for sustainable tourism. Tourism Geographies, 15(1), 25-42.

Gray, B. (1999). Collaborating: Finding common ground for multiparty problems. Retrieved from https://www.worldcat.org/title/collaborating-finding- 
common-ground-for-multipartyproblems/oclc/819438321\&referer=brief_results

Gronau, R. (1980). Home production: A forgotten industry. The Review of Economics and Statistics, 62(3), 408-416. https://doi.org/10.2307/1927108

Gunn, C. A. (2014). Vacationscape: Developing tourist areas. Routledge.

Jafari, J. (1987). Tourism models: The sociocultural aspects. Tourism Management, 8(2), 151-159. https://doi.org/10.1016/0261-5177(87)90023-9

Jamal, T. B., \& Getz, D. (1995). Collaboration theory and community tourism planning. Annals of Tourism Research, 22(1), 186-204. https://doi.org/10.1016/0160-7383(94)00067-3

Johnson, R. B., Onwuegbuzie, A. J., \& Turner, L. A. (2007). Toward a definition of mixed methods research. Journal of Mixed Methods Research, 1(2), 112133. https://doi.org/10.1177/1558689806298224

Lambert, A. J. D., \& Boons, F. A. (2002). Eco-industrial parks: Stimulating sustainable development in mixed industrial parks. Technovation, 22(8), 471-484. https://doi.org/10.1016/S0166-4972(01)00040-2

Landry, C. (2012). The creative city: A toolkit for urban innovators. Retrieved February 21, 2017, from https://www.amazon.com/Creative-City-ToolkitUrban-Innovators/dp/1844075982

Lu, C., \& Chang, J.-L. (2016). Beijing cultural and creative industry policy effect evaluation based on fuzzy comprehensive evaluation. Cluster Computing, 19(4), 2133-2143.

Luo, Y., \& Tung, R. L. (2007). International expansion of emerging market enterprises: A springboard perspective. Journal of International Business Studies, 38(4), 481-498. https://doi.org/10.1057/palgrave.jibs.8400275

Ma, H., \& Zhu, K. (2016, July). Study on the renovation of old industrial district combined with the creative industry in Guangdong, China. 4th International Conference on Civil Engineering and Urban Planning, Beijing, China.

McGee, T. (2009). The spatiality of urbanization: The Policy challenges of megaurban and desakota regions of Southeast Asia. Bangi, Malaysia: LESTARI.

Porter, M. E. (1990). The competitive advantage of nations. Retrieved February 21, 2017, from https://hbr.org/1990/03/the-competitive-advantage-of-nations

Porter, M. E. (1998). Clusters and the new economics of competition. Retrieved February 21, 2017, from https://hbr.org/1998/11/clusters-and-the-neweconomics-of-competition

Porter, M. E. (2000). Location, competition, and economic development: Local clusters in a global economy. Economic Development Quarterly, 14(1), 1534. https://doi.org/10.1177/089124240001400105

Reed, M. G. (1997). Power relations and community-based tourism planning. Annals of Tourism Research, 24(3), 566-591.

Sautter, E. T., \& Leisen, B. (1999). Managing stakeholders a tourism planning model. Annals of Tourism Research, 26(2), 312-328. https://doi.org/10.1016/S0160-7383(98)00097-8 
Winny Astuti, Ariva Sugandi Permana, Qomarun, Alpha Febela, \& Rufia Andisetyana

Integrated Planning Model of Creative Industry-Based Kampung Tourism in Jayengan Surakarta, Indonesia

Scott, A. J. (Ed.). (2001). Global city-regions: trends, theory, policy (1st edition) New York: Oxford University Press.

Setiyani, D. (2014). Hubungan Pola keruangan faktor kondisi pengembangan dengan tingkat keberlanjutan klaster batik kauman dan laweyan di Kota Surakarta. Universitas Sebelas Maret.

Sihombing, A., Gunawijaya, J., Zanny, S. A., \& Pratiwi, A. (2016). Sustainable tourism in rural area development, Case study: Kampung tourism in Wanayasa, Purwakarta, West Java, Indonesia. Journal of Tourism, Hospitality and Sports, 15(0), 16-22. 